\title{
PHYSICAL PROPERTIES AND PARTICLE-SIZE FRACTIONS OF SOIL ORGANIC MATTER IN CROP-LIVESTOCK INTEGRATION ${ }^{(1)}$
}

\author{
Carolina Tirloni $^{(2)}$, Antonio Carlos Tadeu Vitorino ${ }^{(3)}$, Anderson Cristian Bergamin ${ }^{(4)}$ \& \\ Luiz Carlos Ferreira de Souza ${ }^{(3)}$
}

\begin{abstract}
SUMMARY
Crop-livestock integration represents an interesting alternative of soil management, especially in regions where the maintenance of cover crops in notillage systems is difficult. The objective of this study was to evaluate soil physical and chemical properties, based on the hypothesis that a well-managed croplivestock integration system improves the soil quality and stabilizes the system. The experiment was set up in a completely randomized design, with five replications. The treatments were arranged in a $6 \times 4$ factorial design, to assess five crop rotation systems in crop-livestock integration, and native forest as reference of soil undisturbed by agriculture, in four layers (0.0-0.05; 0.05-0.10; 0.10-0.15 and 0.15-0.20 m). The crop rotation systems in crop-livestock integration promoted changes in soil physical and chemical properties and the effects of the different systems were mainly detected in the surface layer. The crops in integrated croplivestock systems allowed the maintenance of soil carbon at levels equal to those of the native forest, proving the efficiency of these systems in terms of soil conservation. The systems influenced the environmental stability positively; the soil quality indicator mineral-associated organic matter was best related to aggregate stability.
\end{abstract}

Index terms: crop rotation, no-tillage system, soil quality, soil carbon, aggregate stability.

\footnotetext{
(1) Part of the doctoral thesis of the first author, participant of the graduate program of Agronomy of the Federal University of Grande Dourados - UFGD. Received for publication in September 27, 2011 and approved in May 10, 2012.

(2) $\mathrm{PhD}$ degree in Agronomy/Crop Production, at the Federal University of Grande Dourados - UFGD. Rodovia Dourados-Itahum, km 12, Dourados (MS). Caixa Postal 533 - CEP 79804-970. E-mail: carol_tirloni@yahoo.com.br

(3) Associate Professor of the Faculdade de Ciências Agrárias, UFGD. Bolsista do CNPq. E-mail: antoniovitorino@ufgd.edu.br; luizsouza@ufgd.edu.br

(4) Assistant Professor of the Federal University of Amazonas, IEAA/UFAM, Humaitá (AM). E-mail: andersonbergamin@hotmail.com
} 


\title{
RESUMO: ATRIBUTOS FÍSICOS E FRACIONAMENTO GRANULOMÉTRICO DA MATÉRIA ORGÂNICA DO SOLO EM SISTEMA DE INTEGRAÇÃO LAVOURA-PECUÁRIA
}

\begin{abstract}
A integração lavoura-pecuária representa uma alternativa interessante de manejo dos solos principalmente nas regiões com ocorrência de clima que impõe dificuldades na formação de massa seca para cobertura do solo em plantio direto. O objetivo deste trabalho foi avaliar atributos físicos e químicos do solo, partindo da hipótese de que a integração lavourapecuária, quando bem manejada, melhora a qualidade do solo e proporciona maior estabilidade ao sistema. $O$ delineamento experimental foi inteiramente casualizado, com cinco repetições. Os tratamentos foram constituídos por um fatorial $6 \times 4$, sendo cinco sistemas de rotação de culturas em integração lavoura-pecuária e a mata nativa utilizada como referência do solo antes das alterações promovidas pelo uso agrícola; e quatro profundidades $(0,0-0,05,0,05-0,10,0,10-0,15$ e 0,15-0,20 m). Os sistemas de rotação de culturas em integração lavoura-pecuária promoveram alterações nos atributos físicos e químicos do solo; os efeitos dos diferentes sistemas manifestaram-se, sobretudo, na camada mais superficial do solo. Os sistemas de rotações descritos permitem manter teores de carbono no solo iguais aos encontrados no ambiente de mata original, comprovando assim a eficiência do sistema de integração lavoura-pecuária com relação à conservação do solo. Esses sistemas influenciam positivamente a estabilidade do ambiente, sendo a matéria orgânica associada à fração mineral o indicador de qualidade do solo mais bem relacionado com a estabilidade de agregados.
\end{abstract}

Termos de indexação: rotação de culturas, sistema plantio direto, qualidade do solo, carbono do solo, estabilidade de agregados.

\section{INTRODUCTION}

The maintenance of agricultural production systems that supply the population with food, fiber and energy, without jeopardizing the prospect of support and survival of future generations, representing an enormous challenge for humanity. In the search for conservation systems, croplivestock integration, which is the diversification, rotation, intercropping and/or series of activities in agriculture and livestock within the same area in harmonic order (Alvarenga \& Noce, 2005), seems to be an alternative of production that can improve the sustainability of agriculture in tropical and subtropical regions.

The integrated crop-livestock systems promote conditions that can increase soil resistance to degradation. According to Costa et al. (2009), the soil physical properties are not changed in integrated croplivestock with annual winter pastures in conservation tillage, including grazing. On the other hand, Bertol et al. (2004) reported that soil physical properties are changed by management, and that systems that raise the soil organic carbon content also increase the mean weight diameter (MWD) of aggregates. In a study on soil aggregate stability in agricultural systems, Salton et al. (2008) found highest percentages of large aggregates in systems with permanent pasture, lowest percentages in no-tillage systems, and intermediate values in crop-pasture rotation. The authors explain that the activity of the grass root system, coupled with the absence of soil disturbance, effectively contributes to the formation of stable macroaggregates.

Some researchers consider soil organic matter (SOM) as an ideal indicator to assess soil quality (Shukla et al., 2006; Salton et al., 2008; Spera et al., 2009), based on its importance in the different physical, chemical and biological processes, which are thoroughly described in the literature. SOM has several functions in the environment, playing a role in essential processes such as nutrient cycling and retention, soil aggregation and water dynamics, as well as being the primary energy source for biological activity (Roscoe, 2006).

Since SOM is very variable in terms of decomposition degree, chemical composition, size, chemical and physical protection, chemical or physical fractionation methods are used to classify and quantify its presence in soil and the effects of management systems. In the physical grain-size fractionation, SOM is subdivided into particulate organic matter (POM) and mineral-associated fraction of soil organic matter, also called mineral (MOM). The particulate is the most labile soil organic fraction, responding readily to management changes, while the mineral fraction is the most stable, with no measurable sensitivity to changes in soil tillage (Salton et al., 2005).

The objective of this study was to evaluate the physical properties and physical fractionation of organic matter in a Hapludox in different croplivestock integration systems. 


\section{MATERIAL AND METHODS}

The study was conducted on the Fazenda Cabeceira, in Maracajú, Mato Grosso do Sul (latitude $22^{\circ} 14$ ' S; longitude $54^{\circ} 49^{\prime} \mathrm{W}$ ). The soil was classified as very clayey texture Oxisol (Embrapa, 2006). Laboratory analyses were performed at the Federal University of Grande Dourados (UFGD), in Dourados, MS. Croplivestock integration was implemented in 1972, and the current model of crop rotation in 2003 (Table 1).

The experiment was arranged in a completely randomized, $4 \times 6$ factorial design with five replications. The treatments consisted of five crop rotation systems in crop-livestock integration (S1, S2, S3, S4, and S5 - Table 1) and of a native forest (NF) area, in four soil layers $(0.0-0.05 ; 0.05-0.10,0.10-0.15$, and $0.15-0.20 \mathrm{~m}$ ).

The no-tillage crops were planted in the summer and winter growing seasons, and the pasture was intensively grazed, at a stocking rate of $4.0 \mathrm{AU} / \mathrm{ha}$ (animal units per hectare) in the summer, decreasing to $1.5 \mathrm{AU} / \mathrm{ha}$ in the winter. The animals were only placed in each system, when the area was cultivated with Brachiaria ruziziensis (Brac) (Table 1). In the rotation systems $\mathrm{S} 1, \mathrm{~S} 2, \mathrm{~S} 3, \mathrm{~S} 4$, and $\mathrm{S} 5$, the animals grazed in the areas in the periods from fall/winter 2006 to spring/summer 2006/07; from fall/winter 2007 to spring/summer 2007/08; from fall/winter 2005 to spring/summer 2005/06; in spring/summer 2003/04; and from fall/winter 2004 to spring/summer 2004/05, respectively. The soil of each rotation system and NF was sampled in February 2008. Bulk density, macroporosity, microporosity, and total porosity were determined according to the methodology proposed by Embrapa (1997). Undisturbed soil was sampled in metal cylinders (diameter $5.57 \mathrm{~cm}$, height $4.1 \mathrm{~cm}$ ) in four layers. After removal, the samples were saturated by gradual increase of the water level to about two thirds of the ring height and microporosity determined by the tension table method. Thereafter, the samples were oven-dried at $105-110{ }^{\circ} \mathrm{C}$ for $48 \mathrm{~h}$ to determine bulk density, total porosity and macroporosity.

The aggregate distribution was determined by the wet-sieving procedure. Undisturbed soil blocks were collected, air-dried and sieved through 9.52 and 4.76 $\mathrm{mm}$. The aggregates retained in the $4.76 \mathrm{~mm}$ sieve were used in the wet analysis of stable aggregates, by sieving the samples through a set of sieves (mesh 2.0, $1.0,0.5$ and $0.105 \mathrm{~mm}$ ) and exposing them to vertical oscillation for $12 \mathrm{~min}$, at a frequency of 40 oscillations per minute. As stability indices, the percentage of aggregates $>1.00 \mathrm{~mm}$ and $<1.00 \mathrm{~mm}$, geometric mean diameter (GMD) and mean weight diameter (MWD) were used, calculated as follows (Kemper \& Rosenau, 1986):

$$
\mathrm{MGD}=10^{[\Sigma(\mathrm{n} \log \mathrm{d}) / \Sigma \mathrm{n}]} \text { and } \mathrm{MWD}=[\Sigma(\mathrm{n} \mathrm{d}) / \Sigma \mathrm{n}]
$$

where $\mathrm{n}=$ aggregate mass retained in a given sieve (g); and d = diameter of a given size aggregate range $(\mathrm{mm})$.

The carbon (C) content of soil samples was determined by wet oxidation, and expressed in $\mathrm{g} \mathrm{kg}^{-1}$ soil (Embrapa, 1997).

SOM was fractionated based on the physical particle sizes. After stirring for $14 \mathrm{~h}$, the samples were sieved though $0.053 \mathrm{~mm}$. The POM retained in the sieve was weighed and the amount of total organic carbon (TOC) of the fraction determined. The data were transformed into contents of the fractions of the total soil mass. It is assumed that the fraction that passes through the sieve contains the MOM fraction, which was calculated as the difference between SOM and $\mathrm{POM}$ and the $\mathrm{C}$ content in it was also determined by subtraction (Salton et al., 2005).

Table 1. History and description of the crop rotation systems in crop-livestock integration between 2003 and 2008, in their respective growing seasons

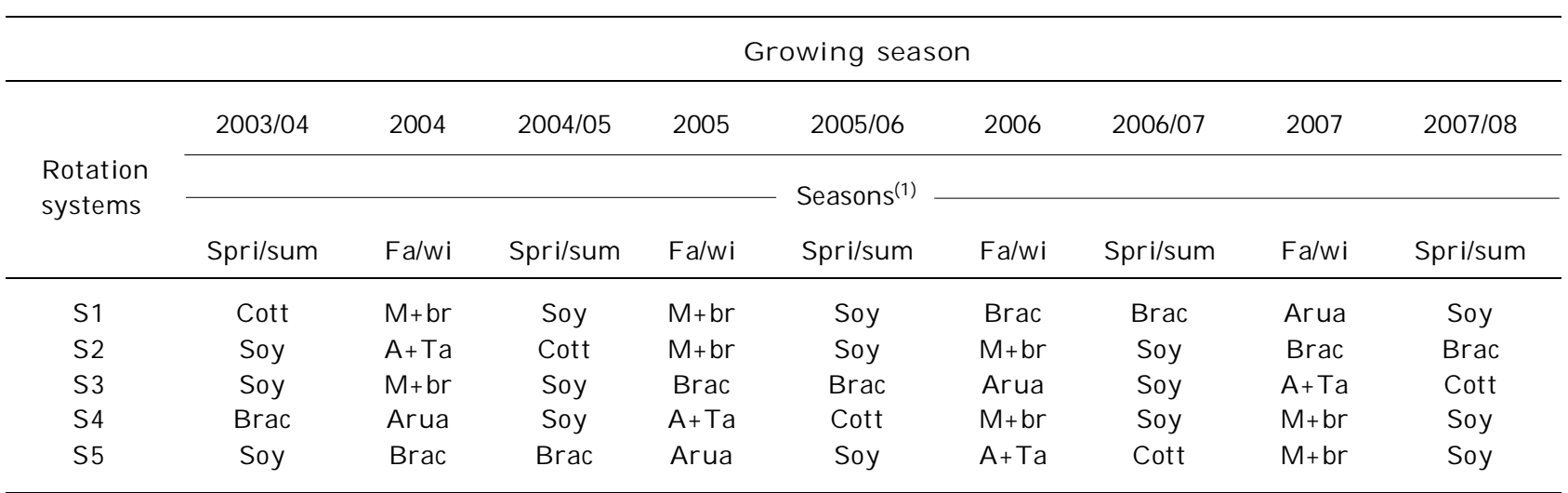

Cott = cotton $; \mathrm{M}+\mathrm{br}=$ Maize + Brachiaria ruziziensis $;$ Brac = Brachiaria ruziziensis $;$ Arua = aruana grass $; \mathrm{A}+\mathrm{Ta}=\mathrm{Oat}+$ Tanzania grass. ${ }^{(1)}$ Spri/sum $=$ Spring/summer; Fa/wi $=$ Fall/winter. 
These data were used to compute some indices, as proposed by Rangel et al. (2008), as follows:

a) the carbon pool index (CPI): given by the ratio between the $\mathrm{C}$ stock in each treatment and $\mathrm{C}$ stock in the control environment NF

$\mathrm{CPI}=$ carbon pool in a treatment/ carbon pool in the forest

b) Lability (L): ratio between particulate organic $\mathrm{C}$ and mineral organic $\mathrm{C}$ amounts in each treatment

$\mathrm{L}=$ particulate organic carbon / carbon organic mineral

c) Lability index: lability relationship between each treatment and the reference environment $\mathrm{NF}$

\section{$\mathrm{LI}=\mathrm{L}$ in a treatment $/ \mathrm{L}$ in $\mathrm{NF}$}

d) carbon management index: product of the $\mathrm{C}$ stability index by the lability index

$$
\mathrm{CMI}(\%)=(\mathrm{CPI} \times \mathrm{LI}) \times 100
$$

Accumulated carbon/carbon pool was computed as the product of its contents ( $\mathrm{g} \mathrm{kg}^{-1}$ of soil) and soil density in the corresponding area and layer (in $\mathrm{g} \mathrm{dm}^{-3}$ ) and transformed into $\mathrm{Mg} \mathrm{ha}^{-1}$, when a specific layer is considered:

\section{e) Stock C = Ct x Ds x layer thickness $(\mathrm{cm})$}

The results were subjected to analysis of variance and when significant, the Tukey test was applied at 5 $\%$ for mean comparison. Simple linear correlations for pair combinations were also established, with the soil physical and chemical properties studied. For this purpose, the program SAEG was used (Ribeiro Júnior, 2001).

\section{RESULTS AND DISCUSSION}

The crop rotation systems in crop-livestock integration affected soil density, macroporosity and total porosity, mainly from the surface to a depth of $0.05 \mathrm{~m}$. In system S2, significant compaction was inferred from the density (Table 2). It is noteworthy that at the time of soil sampling, the S2 area was used as Brachiaria ruziziensis pasture grazed by cattle. Consequently, the higher bulk density in this area was related to previous animal trampling. Also, several authors observed changes in soil physical properties under no-tillage only in the surface layer $(0.0-0.10 \mathrm{~m})$, when pressure was applied to the soil surface (Collares et al., 2006; Freddi et al., 2007; Bergamin et al., 2010). In the sub-surface (0.05 - 0.20 $\mathrm{m})$, high density and low total soil porosity values were observed in all crop rotation systems in croplivestock integration, compared with NF (Table 2), which are related to the likely occurrence of compaction in this soil layer.
In the soil layers studied, bulk density was lowest in NF. This confirms results of Serafim et al. (2008), who reported higher bulk density in integrated croplivestock systems. In the $0.0-0.05 \mathrm{~m}$ layer, bulk density was highest in system $\mathrm{S} 2$, due to the most recent animal trampling (Table 2). Bulk density was lowest in the 0.0 - $0.05 \mathrm{~m}$ layer (Table 2). In S2, bulk density did not differ between soil layers. For Bertol et al. (1998), the pressure of animal trampling causes changes in the soil density and porosity, especially between 0.03 and $0.06 \mathrm{~m}$. Souza et al. (1998) reported that the trampling of one head of adult cattle causes a pressure of $190 \mathrm{kPa}$ on the soil. In a very clayey Oxisol under annual crops, Bergamin et al. (2010) found that pressure above $220 \mathrm{kPa}$ applied to the soil increased density and reduced soil macroporosity and total porosity.

In the succession of the systems $\mathrm{S} 4$ and $\mathrm{S} 5$, from planted pasture to crops, a reduction in bulk density was observed (Table 2). The supply of organic material in these systems, root growth and decomposition result in the formation of root channels contributing to reduce bulk density. Siqueira Júnior (2005) observed that the effect of animal trampling causing increased soil bulk density is minimized in the long term, when the pasture is left ungrazed in certain periods. For Braida et al. (2006), the residues on the soil contribute to dissipate the compaction energy, reducing density. The same authors reported that the strong interaction between organic matter and clay particles minimized the effect of trampling more strongly in clay than in sandy soils. In a study conducted in a very clayey Oxisol, Argenton et al. (2005) reported that when bulk density exceeds $1.30 \mathrm{~g} \mathrm{~cm}^{-3}$, root growth should be supported by management practices, particularly by planting crops that produce large amounts of organic waste.

Macroporosity values were highest in the $0.0-0.05$ $m$ layer in the system S5 and NF (Table 2), whereas lowest values were found in S1, S2 and S3. In the same layer, total porosity was lowest in S1, S2 and S3, indicating greater soil compaction. This result may be due to more recent animal trampling in these systems and the shorter time of cultivation than in S4 and S5, as mentioned by Siqueira Júnior (2005). In the $0.05-0.20 \mathrm{~m}$ layer, macroporosity did not differ between the rotation systems (Table 2). For Lanzanova et al. (2007), soil compaction caused by animal trampling was limited to the surface soil layer 0.0 $0.05 \mathrm{~m}$, while in the deeper layers, there was no difference between the integrated crop-livestock systems. However, this effect may be temporary and reversible (Cassol, 2003). For total porosity, greatest changes were observed in $\mathrm{S} 4$, where the values of this parameter decreased in the deeper soil layers.

The macropore volume decreases significantly with increasing compaction caused by mechanical pressure on the soil, be it by animal trampling or by machinery traffic in no-tillage systems. For Bertol et al. (2000), macroporosity is the soil property that is most 
intensely affected by mechanical pressure. For Bergamin et al. (2010), this indicator of soil quality is best correlated with root development and subsequent plant growth. Macroporosity values below $0.10 \mathrm{~m}^{3} \mathrm{~m}^{-3}$ were found in the systems S1, S2 and S3 $(0.0-0.20 \mathrm{~m})$, a value considered critical by Pagliai et al. (2003), to allow the gaseous and liquid exchanges between soil and atmosphere. Feng et al. (2002) reported that in clay soils, a macroporosity of $0.10 \mathrm{~m}^{3} \mathrm{~m}^{-3}$ is sufficient to inhibit an adequate oxygen supply of crops, requiring macroporosity $>0.10 \mathrm{~m}^{3} \mathrm{~m}^{-3}$ to ensure aeration porosity.

For microporosity, the crop rotation systems in crop-livestock integration were only effective in the deeper soil layers, with no statistical differences. When comparing the values of micropores in different layers, the percentages of micropores were higher in the layers $0.0-0.05$ and $0.05-0.10 \mathrm{~m}$, with 24.1 and $22.9 \%$, respectively. These higher values at the surface are consistent with the effect of pressure by cattle trampling and machinery traffic in the study area. According to Collares et al. (2006), the intensive use of agricultural machinery promotes increased compaction, mainly in the $0.0-0.10$ m layer.

Aggregate stability has been used as an indicator of soil physical quality, as it is sensitive to changes in soil management (Wohlenberg et al., 2004; Wendling et al., 2005; Ferreira et al., 2007; Salton et al., 2008). The geometric mean diameter (GMD), mean weight diameter of aggregates (MWD), aggregates $>1 \mathrm{~mm}$ and aggregates $<1 \mathrm{~mm}$ did not differ between the rotations and $\mathrm{NF}$ in the $0.0-0.05 \mathrm{~m}$ layer, but differences were observed in the deeper layers (Table 3 ). The MGD decreased with soil depth in all rotation systems studied, confirming the observations of Silva $\&$ Ferreira (2005). This same trend was observed for the MWD parameters and aggregates $>1 \mathrm{~mm}$.

In different systems of crop rotation and succession, Wohlenberg et al. (2004) found a correlation between the percentage of aggregates $>2 \mathrm{~mm}$ and SOM. The systems that led to increased SOM levels contributed to a higher percentage of aggregates $>2 \mathrm{~mm}$, whereas systems with no soil cover reduced the levels of soil C and percentage of aggregates $>2 \mathrm{~mm}$. Cultural practices that promote increased residue deposition on the soil proved efficient in increasing aggregate stability, since aside from increasing $C$ inputs, they minimize the direct raindrop impact (Wendling et al., 2005). In a management comparison, Calonego \& Rosolem (2008) found higher MWD in the $0.05-0.10$ layer under no-tillage and cover crops when compared to chiseling.

Analyzing the contents of particulate organic matter (POM), higher values were observed in NF

Table 2. Bulk density, macroporosity and total porosity in four layers of different crop rotation systems in crop-livestock integration

\begin{tabular}{|c|c|c|c|c|c|c|}
\hline \multicolumn{7}{|c|}{ Crop rotation in integrated crop-livestock systems } \\
\hline Layer & $\mathbf{S 1}$ & S2 & S3 & $\mathbf{S 4}$ & S5 & M \\
\hline $\mathrm{m}$ & & & \multicolumn{2}{|c|}{ Bulk density $\left(\mathrm{Mg} \mathrm{m}^{-3}\right)$} & & \\
\hline $0.0-0.05$ & $1.31 \mathrm{Cb}$ & $1.57 \mathrm{Aa}$ & $1.37 \mathrm{Bb}$ & $1.21 \mathrm{Dd}$ & $1.14 \mathrm{Ec}$ & $0.94 \mathrm{Fb}$ \\
\hline $0.05-0.10$ & $1.45 \mathrm{Ba}$ & $1.55 \mathrm{Aa}$ & $1.47 \mathrm{Bba}$ & $1.40 \mathrm{Cc}$ & $1.57 \mathrm{Aa}$ & $1.24 \mathrm{Da}$ \\
\hline $0.10-0.15$ & $1.46 \mathrm{Ca}$ & $1.57 \mathrm{Aa}$ & $1.45 \mathrm{Ca}$ & $1.51 \mathrm{Bb}$ & $1.50 \mathrm{Bb}$ & $1.26 \mathrm{Da}$ \\
\hline $0.15-0.20$ & $1.47 \mathrm{Ba}$ & $1.56 \mathrm{Aa}$ & $1.44 \mathrm{Ba}$ & $1.56 \mathrm{Aa}$ & $1.53 \mathrm{Aab}$ & $1.24 \mathrm{Ca}$ \\
\hline \multirow[t]{2}{*}{ CV\% } & 5.11 & & & & & \\
\hline & & & \multicolumn{2}{|c|}{ Macroporosity $\left(\mathrm{m}^{3} \mathrm{~m}^{-3}\right)$} & & \\
\hline $0.0-0.05$ & $0.09 \mathrm{Ca}$ & $0.05 \mathrm{Cab}$ & $0.10 \mathrm{Ca}$ & $0.22 \mathrm{Ba}$ & $0.30 \mathrm{Aa}$ & $0.31 \mathrm{Aa}$ \\
\hline $0.05-0.10$ & $0.07 \mathrm{Bab}$ & $0.08 \mathrm{Ba}$ & $0.07 \mathrm{Ba}$ & $0.13 \mathrm{ABb}$ & $0.10 \mathrm{Bb}$ & $0.19 \mathrm{Ab}$ \\
\hline $0.10-0.15$ & $0.08 \mathrm{Bab}$ & $0.05 \mathrm{Bab}$ & $0.08 \mathrm{Ba}$ & $0.09 \mathrm{Bc}$ & $0.09 \mathrm{Bb}$ & $0.17 \mathrm{Ab}$ \\
\hline $0.15-0.20$ & $0.06 \mathrm{Bb}$ & $0.05 \mathrm{Bb}$ & $0.08 \mathrm{Ba}$ & $0.05 \mathrm{Bd}$ & $0.08 \mathrm{Bb}$ & $0.18 \mathrm{Ab}$ \\
\hline \multirow[t]{2}{*}{ CV\% } & 2.37 & & & & & \\
\hline & & & \multicolumn{2}{|c|}{ Total porosity $\left(\mathrm{m}^{3} \mathrm{~m}^{-3}\right)$} & & \\
\hline $0.0-0.05$ & $0.35 \mathrm{Ca}$ & $0.27 \mathrm{Ca}$ & $0.36 \mathrm{BCab}$ & $0.43 \mathrm{ABa}$ & $0.49 \mathrm{Aa}$ & $0.52 \mathrm{Aa}$ \\
\hline $0.05-0.10$ & $0.31 \mathrm{ABb}$ & $0.29 \mathrm{Ba}$ & $0.33 \mathrm{ABb}$ & $0.34 \mathrm{ABb}$ & $0.31 \mathrm{ABb}$ & $0.40 \mathrm{Ab}$ \\
\hline $0.10-0.15$ & $0.32 \mathrm{ABb}$ & $0.27 \mathrm{Ba}$ & $0.34 \mathrm{ABb}$ & $0.30 \mathrm{ABc}$ & $0.31 \mathrm{ABb}$ & $0.39 \mathrm{Ab}$ \\
\hline $0.15-0.20$ & $0.30 \mathrm{ABb}$ & $0.28 \mathrm{Ba}$ & $0.38 \mathrm{Aa}$ & $0.28 \mathrm{Bc}$ & $0.31 \mathrm{ABb}$ & $0.39 \mathrm{Ab}$ \\
\hline CV\% & 9.87 & & & & & \\
\hline
\end{tabular}

Means followed by the same capital letter in the row and lowercase letter in the column did not differ statistically from each other by the Tukey test at $5 \%$. 
Table 3. Mean geometric diameter, mean weight diameter, aggregates $>1 \mathrm{~mm}$ and aggregates $<1 \mathrm{~mm}$ in four soil layers of different crop rotation systems in crop-livestock integration

\begin{tabular}{|c|c|c|c|c|c|c|}
\hline \multicolumn{7}{|c|}{ Crop rotation in integrated crop-livestock systems } \\
\hline Layer & S1 & S2 & S3 & $\mathbf{S 4}$ & S5 & $\mathbf{M}$ \\
\hline $\mathrm{m}$ & & & \multicolumn{2}{|c|}{ Mean geometric diameter $(\mathrm{mm})$} & & \\
\hline $0.0-0.05$ & $2.77 \mathrm{Aa}$ & $2.77 \mathrm{Aa}$ & $2.81 \mathrm{Aa}$ & $2.77 \mathrm{Aa}$ & $2.81 \mathrm{Aa}$ & $2.80 \mathrm{Aa}$ \\
\hline $0.05-0.10$ & $2.59 \mathrm{Bb}$ & $2.51 \mathrm{Bb}$ & $2.79 \mathrm{Aa}$ & $2.72 \mathrm{Aab}$ & $2.62 \mathrm{ABb}$ & $2.86 \mathrm{Aa}$ \\
\hline $0.10-0.15$ & $2.73 \mathrm{ABa}$ & $2.75 \mathrm{Aa}$ & $2.62 \mathrm{BCb}$ & $2.62 \mathrm{BCab}$ & $2.56 \mathrm{Cb}$ & $2.81 \mathrm{Aa}$ \\
\hline $0.15-0.20$ & $2.24 \mathrm{Cc}$ & $2.67 \mathrm{ABCa}$ & $2.37 \mathrm{Cc}$ & $2.57 \mathrm{Bb}$ & $2.33 \mathrm{Cc}$ & $2.76 \mathrm{Aa}$ \\
\hline \multirow[t]{2}{*}{ CV\% } & 7.18 & & & & & \\
\hline & & & \multicolumn{2}{|c|}{ Mean weight diameter (mm) } & & \\
\hline $0.0-0.05$ & $2.85 \mathrm{Aa}$ & $2.84 \mathrm{Aa}$ & $2.86 \mathrm{Aa}$ & $2.84 \mathrm{Aa}$ & $2.83 \mathrm{Aa}$ & $2.85 \mathrm{Aa}$ \\
\hline $0.05-0.10$ & $2.76 \mathrm{Bb}$ & $2.76 \mathrm{Bb}$ & $2.85 \mathrm{Aa}$ & $2.82 \mathrm{ABa}$ & $2.77 \mathrm{Bb}$ & $2.87 \mathrm{Aa}$ \\
\hline $0.10-0.15$ & $2.81 \mathrm{ABa}$ & $2.83 \mathrm{ABa}$ & $2.77 \mathrm{BCb}$ & $2.78 \mathrm{BCb}$ & $2.74 \mathrm{Cb}$ & $2.85 \mathrm{Aa}$ \\
\hline $0.15-0.20$ & $2.66 \mathrm{Cc}$ & $2.79 \mathrm{Aab}$ & $2.67 \mathrm{Cc}$ & $2.76 \mathrm{Bb}$ & $2.64 \mathrm{Cc}$ & $2.83 \mathrm{Aa}$ \\
\hline $\mathrm{CV} \%$ & 31.03 & & \multirow{2}{*}{\multicolumn{2}{|c|}{ Aggregate size > $1 \mathrm{~mm}(\%)$}} & & \\
\hline & & & & & & \\
\hline $0.0-0.05$ & $98.69 \mathrm{Aa}$ & $98.48 \mathrm{Aa}$ & $99.03 \mathrm{Aa}$ & $98.38 \mathrm{Aa}$ & $98.09 \mathrm{Aa}$ & 98.59 Aab \\
\hline $0.05-0.10$ & $95.32 \mathrm{Bb}$ & $95.37 \mathrm{Bb}$ & $98.76 \mathrm{Aa}$ & $97.71 \mathrm{ABa}$ & $95.59 \mathrm{ABb}$ & $99.62 \mathrm{Aa}$ \\
\hline $0.10-0.15$ & $97.20 \mathrm{ABa}$ & $97.74 \mathrm{ABb}$ & $95.32 \mathrm{Bb}$ & $95.38 \mathrm{Bb}$ & $94.30 \mathrm{Bb}$ & $98.77 \mathrm{Aab}$ \\
\hline $0.15-0.20$ & $91.52 \mathrm{Cc}$ & $96.48 \mathrm{Ab}$ & $91.66 \mathrm{Cc}$ & $95.00 \mathrm{Bb}$ & $90.06 \mathrm{Cc}$ & $97.68 \mathrm{Ab}$ \\
\hline \multirow[t]{2}{*}{ CV\% } & 66.57 & & & & & \\
\hline & & & \multicolumn{2}{|c|}{ Aggregate size $<1 \mathrm{~mm}(\%)$} & & \\
\hline $0.0-0.05$ & $1.31 \mathrm{Ac}$ & $1.52 \mathrm{Ab}$ & $0.97 \mathrm{Ac}$ & $1.62 \mathrm{Ab}$ & $1.91 \mathrm{Ac}$ & $1.41 \mathrm{Aa}$ \\
\hline $0.05-0.10$ & $4.68 \mathrm{Ab}$ & $4.63 \mathrm{Aa}$ & $1.24 \mathrm{Bc}$ & $2.29 \mathrm{Bb}$ & $4.41 \mathrm{ABb}$ & $0.38 \mathrm{Bb}$ \\
\hline $0.10-0.15$ & $2.80 \mathrm{Bc}$ & $2.26 \mathrm{Bb}$ & $4.68 \mathrm{ABb}$ & $4.17 \mathrm{ABa}$ & $5.70 \mathrm{Ab}$ & $1.23 \mathrm{Ba}$ \\
\hline $0.15-0.20$ & $8.48 \mathrm{ABa}$ & $3.52 \mathrm{Cab}$ & $8.34 \mathrm{Aa}$ & $5.00 \mathrm{BCa}$ & $9.94 \mathrm{Aa}$ & $2.32 \mathrm{Ca}$ \\
\hline CV\% & 2.43 & & & & & \\
\hline
\end{tabular}

Means followed by the same capital letter in the row and lowercase letter in the column did not differ statistically from each other by the Tukey test at $5 \%$.

and systems S3 and S4 in the 0.0 - 0.05 m layer (Table 4). This may be related to the high amount of plant residues on the soil surface. It was also noted that POM was efficient to indicate differences between the rotation systems studied in crop-livestock integration, mainly in the $0.0-0.05 \mathrm{~m}$ layer. Similar reports, of higher POM levels in the $0.0-0.05$ m layer, making the differentiation of management systems possible according to the deposition of organic material on the soil, were published by Nicoloso et al. (2008) and Loss et al. (2009). No changes in POM caused by crop rotation systems in crop-livestock integration were observed in the $0.15-0.20$ m layer (Table 4).

The highest POM values were found in the soil surface in all systems. The reason was that the integrated crop-livestock management under study was a no-tillage system, in which crop residues are left on the soil surface. Loss et al. (2009) also found highest values of particulate organic $\mathrm{C}$ in the 0.0 $0.05 \mathrm{~m}$ layer.

The differences between mineral-associated organic matter (MOM) were only statistically significant between the systems (Table 5). The average contents of this decay-resistant organic matter were statistically the same in almost all treatments, except in S5, where the MOM concentrations were lower than in NF and the S3 system. This confirms the stability of the other crop rotation systems in crop-livestock integration. For Bayer et al. (2004), this stability is due to slow cycling in terms of MOM formation and decay, requiring long periods for changes. In addition, the physical protection of MOM particles contained within microaggregates $<0.053 \mathrm{~mm}$, contributes to the high stability of this organic matter fraction interfering with the direct action of decomposing microorganisms.

The content of total organic carbon (TOC) in NF was higher than in the other systems. The TOC value was lower in S5 than in the system S3 and NF (Table 5). In the integrated crop-livestock system, each treatment tested produced different amounts of plant and animal organic waste, according to the rotation system of each area. In the areas with lower amounts of these residues, the decomposition and also the dynamics of chemical reactions in the soil may 
Table 4. Mean values of particulate organic matter $\left(\mathrm{g} \mathrm{kg}^{-1}\right)$ in four soil layers of different crop rotations and integrated crop-livestock systems

\begin{tabular}{|c|c|c|c|c|c|c|}
\hline \multicolumn{7}{|c|}{ Crop rotation in integrated crop-livestock systems } \\
\hline Layer & S1 & S2 & S3 & $\mathbf{S 4}$ & S5 & $\mathbf{M}$ \\
\hline $\mathrm{m}$ & & & \multicolumn{2}{|c|}{ Particulate organic matter $\left(\mathrm{g} \mathrm{kg}^{-1}\right)$} & & \\
\hline $0.0-0.05$ & $8.73 \mathrm{Ba}$ & $8.26 \mathrm{Ba}$ & $10.51 \mathrm{Aa}$ & $10.17 \mathrm{ABa}$ & $6.19 \mathrm{Ca}$ & $15.69 \mathrm{Aa}$ \\
\hline $0.05-0.10$ & $2.50 \mathrm{Bb}$ & $2.32 \mathrm{Bb}$ & $2.74 \mathrm{Bb}$ & $2.82 \mathrm{Bb}$ & $1.46 \mathrm{Bb}$ & $4.77 \mathrm{Ab}$ \\
\hline $0.10-0.15$ & $1.45 \mathrm{Bc}$ & $1.20 \mathrm{Bc}$ & $1.33 \mathrm{Bc}$ & $1.50 \mathrm{ABc}$ & $0.90 \mathrm{Bb}$ & $3.31 \mathrm{Ac}$ \\
\hline $0.15-0.20$ & $1.11 \mathrm{Ac}$ & $0.95 \mathrm{Ac}$ & $0.97 \mathrm{Ac}$ & $1.01 \mathrm{Ac}$ & $0.67 \mathrm{Ab}$ & $2.15 \mathrm{Ad}$ \\
\hline $\mathrm{CV} \%$ & 33.29 & & & & & \\
\hline
\end{tabular}

Means followed by the same capital letter in the row and lowercase letter in the column did not differ statistically from each other by the Tukey test at $5 \%$.

Table 5. Mean values of mineral-associated organic matter (MOM), total organic carbon (TOC) and lability in different crop rotation systems in crop-livestock integration

\begin{tabular}{clll}
\hline \multirow{2}{*}{ Management } & MOM & TOC & Lability \\
\hline & & $\mathrm{g} \mathrm{kg}^{-1}$ & \\
\cline { 2 - 3 } M & $24.68 \mathrm{~A}$ & $31.16 \mathrm{~A}$ & $0.24 \mathrm{~A}$ \\
S1 & $21.10 \mathrm{AB}$ & $24.74 \mathrm{BC}$ & $0.16 \mathrm{~B}$ \\
S2 & $21.01 \mathrm{AB}$ & $24.54 \mathrm{BC}$ & $0.15 \mathrm{~B}$ \\
S3 & $22.19 \mathrm{~A}$ & $26.08 \mathrm{~B}$ & $0.17 \mathrm{~B}$ \\
S4 & $20.86 \mathrm{AB}$ & $24.20 \mathrm{BC}$ & $0.13 \mathrm{~B}$ \\
S5 & $17.74 \mathrm{~B}$ & $20.05 \mathrm{C}$ & $0.13 \mathrm{~B}$ \\
CV\% & 17.39 & 13.60 & 38.17 \\
\hline
\end{tabular}

Means followed by the same capital letter in the column did not differ statistically from each other by the Tukey test at $5 \%$.

increase, with a rapid SOM mineralization, leading to differences between the TOC in each area. Furthermore, Carneiro et al. (2008) reported that these differences may be related to the differences in the decomposition process of legumes and grasses, which depends on the $\mathrm{C} / \mathrm{N}$ ratio of plant species, climate and soil microbial activity.

Lability values were highest in NF, and did not differ significantly from each other in the other systems (Table 5). This suggests that some of the particulate $\mathrm{C}$ in the native soil had been degraded by anthropogenic interference, i.e., deforestation and installation of crop rotation systems in crop-livestock integration. Since MOM is usually less modified by different management forms, especially in the short term (Bayer et al., 2004), the mean lability values in the forest are naturally higher.

In the different layers, the levels of MOM, TOC, lability, lability index (LI) and carbon management index (CMI) were highest in the layer $0.0-0.05 \mathrm{~m}$
(Table 6). This is mostly due to the large amount of organic residues deposited on the soil surface. Loss et al. (2009) detected differences in MOM between layers and reported that these differences may be associated with agricultural practices, e.g., green manure, crop rotation and/or intercropping, organic fertilization, and maintenance of plant residues on the soil surface. For TOC, the same trend was observed in the different layers as for MOM (Table 6). It is noteworthy that in tropical environments, the process of land degradation is closely related to SOM.

Lability is reduced in the deeper soil layers (Table 6 ), because the surface layer is the most influenced by soil management, with respect to the input of organic material, especially in no-tillage, where a minimal soil disturbance is expected. Thus, in the deeper layers, SOM is associated with minerals, with slow cycling in terms of SOM formation and decay, requiring long periods for alterations. Silva et al. (1994) observed significant C losses caused by deforestation and soil cultivation, accompanied by the consumption of the more labile organic fractions.

The average LI and CMI were highest in the 0.0 $0.05 \mathrm{~m}$ layer, higher than in the other layers, which did not differ from each other (Table 6). No significant differences were observed for CMI between the rotation systems and NF, showing that the tested systems can increase the preservation and restore the levels and/or quality of the organic fractions in the studied area. When computing the CMI, the distribution patterns and carbon contents of compartments related to the chemical composition of SOM may differ from one site and one crop to another and not reflect the conditions observed in areas with natural vegetation, which are almost always the best to ensure the functionality of the matrix soil (Rangel et al., 2008).

The differences between the CPI in the systems were highest to a depth of $0.15 \mathrm{~m}$ (Table 7). All crop rotation systems had lower CPI than NF. It was found that the conversion of native vegetation to agricultural 
production can drastically reduce the SOM levels since the supply of residues is reduced and the decomposition rate increased, while erosion losses from the soil surface layers are greater (Carter, 2001; Christensen, 2001).

Silva et al. (1994) analyzed 220 samples of three soil classes in the cerrado region under continuous soybean, using heavy machinery. After five crop years, the authors observed a SOM loss of $80 \%$, compared to the initial content for Quartzipsamments, $76 \%$ for medium texture Red Yellow Latosols and $41 \%$ for clayey Red Yellow Latosols. This smaller SOM loss in clayey Oxisols can be explained by the high levels of $\mathrm{Fe}$ and $\mathrm{Al}$ oxy-hydroxides that can complex SOM, increasing its stability (Roscoe et al., 2000). In a very clayey Oxisol, Roscoe \& Burman (2003) found similar carbon pool levels in areas of native savannah vegetation with corn - common bean succession for 30 years.

Most $\mathrm{C}$ was accumulated in the systems $\mathrm{S} 2$ and $\mathrm{S} 3$ in the layer $0.0-0.05 \mathrm{~m}$ (Table 7). This may be related to the continuous cultivation of Brachiaria in S2 and oat + Tanzania grass with subsequent cotton (fall/winter 2007 and spring/summer 2007/2008, respectively) in S3. The inclusion of these grasses (Brachiaria and oat + Tanzania grass) may have contributed to raise the $\mathrm{C}$ pool levels mainly in the surface layer by the higher input of plant residues of these species in the rotation systems, as observed by Salton et al. (2008). In the $0.05-0.20$ m layer, S1, S2, S3, and NF showed no significant differences (Table 7), and the differences in $\mathrm{C}$ accumulation between the cultivation systems decreased in the deeper layers of the soil profile.

Table 6. Mean values of mineral-associated organic matter (MOM), total organic carbon (TOC), lability, lability index (LI), and carbon management index (CMI) in four layers

\begin{tabular}{llcccc}
\hline \multirow{2}{*}{ Layer } & MOM & TOC & Lability & LI & CMI \\
\hline m & & & $\mathrm{g} \mathrm{kg}^{-1}$ & \\
\cline { 2 - 6 } $0-0.05$ & $26.54 \mathrm{~A}$ & $36.47 \mathrm{~A}$ & $0.39 \mathrm{~A}$ & $1.00 \mathrm{~A}$ & $92.82 \mathrm{~A}$ \\
$0.05-0.10$ & $22.17 \mathrm{~B}$ & $24.96 \mathrm{~B}$ & $0.12 \mathrm{~B}$ & $0.69 \mathrm{~B}$ & $60.31 \mathrm{~B}$ \\
$0.10-0.15$ & $19.05 \mathrm{C}$ & $20.66 \mathrm{C}$ & $0.08 \mathrm{BC}$ & $0.53 \mathrm{~B}$ & $44.57 \mathrm{~B}$ \\
$0.15-0.20$ & $17.29 \mathrm{C}$ & $18.43 \mathrm{C}$ & $0.06 \mathrm{C}$ & $0.52 \mathrm{~B}$ & $38.23 \mathrm{~B}$ \\
CV\% & 17.39 & 13.60 & 38.17 & 35.73 & 42.33 \\
\hline
\end{tabular}

Means followed by the same capital letter in the column did not differ statistically from each other by the Tukey test at $5 \%$.

Table 7. Carbon pool index and accumulated carbon in four soil layers of different crop rotation systems in crop-livestock integration

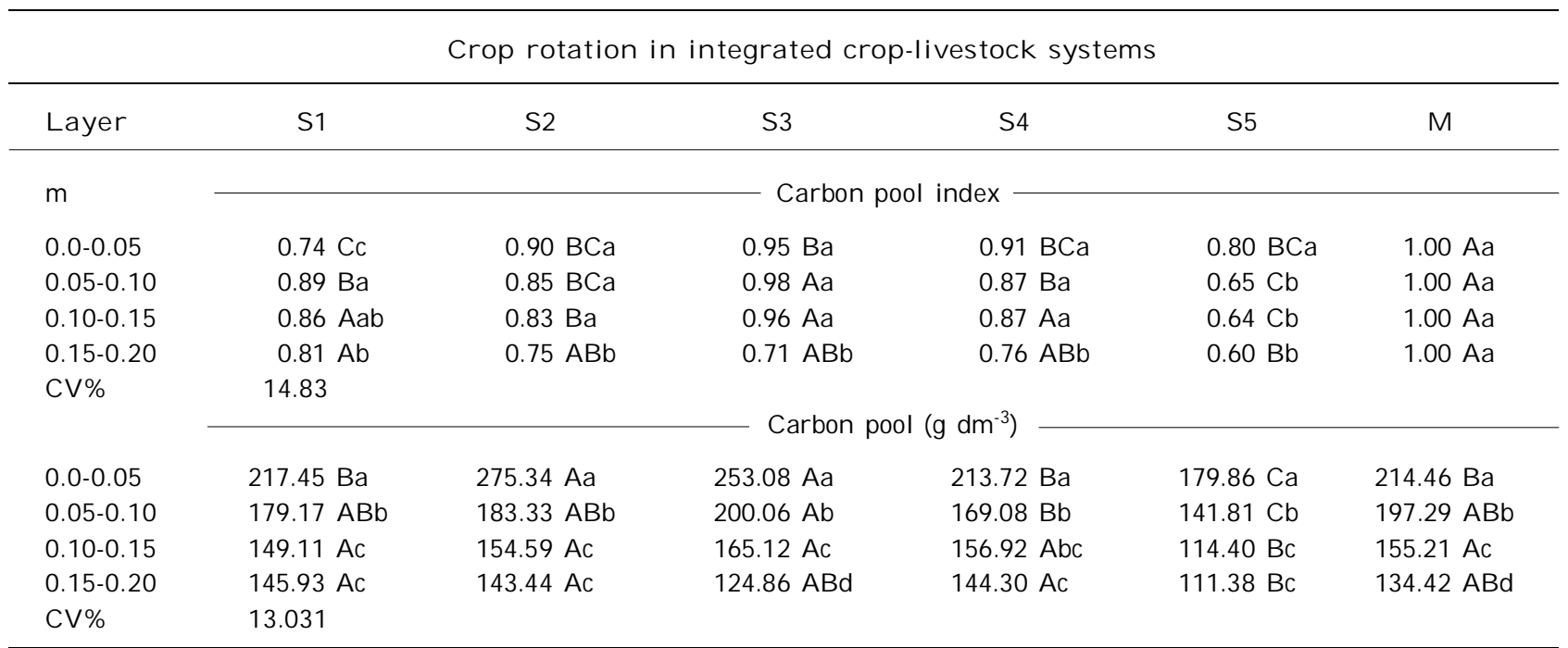

Means followed by same capital letters in he row and lowercase letters in the column did not differ from each other by the Tukey test at $5 \%$. 
S5 accumulated the least $\mathrm{C}$ in the soil (Table 7), which can be attributed to the cotton crop that had been included very recently in this system (spring/ summer growing season of 2006/07) compared to the systems S1, S2 and S4. At the time of soil sampling, cotton was being grown in the $\mathrm{S} 3$ area, but unlike in $\mathrm{S} 5$, no reduction in $\mathrm{C}$ accumulation was observed. This may be due to the short period since the crop had been included in this system, indicating little influence of crops in early development. However, even when cotton is used, which usually acts as a C source for the atmosphere when grown in monoculture, planted in rotation with other crops, there seems to be a mechanism of restoration of the $\mathrm{C}$ levels in the soil promoted by the other crops of the systems studied. For Rangel et al. (2008), reductions in C pools and changes in the SOM composition affect the sustainability of agroecosystems.

Corazza et al. (1999) studied different management systems as $\mathrm{C}$ source or deposit for cerrado vegetation and concluded that in relation to the natural system, more $\mathrm{C}$ was accumulated in systems without soil disturbance (no-tillage, planted pasture and eucalyptus reforestation) and lowest in the tilled systems (disk plow and heavy disk harrow), which acted as $\mathrm{C} \mathrm{CO}_{2}$ deposit and source to the atmosphere, respectively.

For the simple linear correlation coefficients, negative correlations of bulk density and aggregates $<1 \mathrm{~mm}$ with all SOM-related properties were detected (Table 8). This shows that soil bulk density and aggregates $<1 \mathrm{~mm}$ decrease with increasing SOM levels and quality. The property with the highest correlation coefficient with bulk density was LI, where only the correlation of bulk density with $\mathrm{C}$ buildup was non-significant.

The formation and stability of aggregates $<1 \mathrm{~mm}$ was not positively correlated with SOM. Vitorino et al. (2003) studied the stability of silt-sized aggregates, reported the importance of $\mathrm{Al}$ compounds and clay fraction mineralogy in the formation of silt-sized aggregates. Similarly, Pedrotti et al. (2003) reported high correlations between soil aggregates and the contents of aluminum oxides, mainly in amorphous forms, which allow a granular structure. Therefore, the data obtained in this study are consistent with the standpoint of others that consider the role of SOM in microaggregate formation and stability as little relevant.

The values of total porosity and of macroporosity were positively correlated with the SOM-related properties; a non-significant correlation was only observed between total porosity and carbon pool (Table 7). There was no significant correlation between the microporosity values and SOM-related properties, showing that the contribution of organic material to soil causes no change in microporosity of the same.

The GMD, MWD and aggregates $>1 \mathrm{~mm}$ were positively correlated with the SOM properties. For Wendling et al. (2005), aggregate stability, expressed by several properties is positively and significantly correlated with soil organic $\mathrm{C}$. The macroaggregates formed by physical processes, by means of mechanical operations and equipment impact or by animal trampling, may be unstable. The factors that increase aggregate stability however, are cementing agents linked to biological aspects, e.g., microbial activity, root exudate release, and tissue growth and death, among others (Salton et al., 2008). These authors reported the importance of relations between the MWD and the organic $\mathrm{C}$ pool, confirming the statement of Christensen (2001) that, aside from the interactions between minerals, the interaction of these with SOM strongly affects the size of waterstable aggregates.

Table 8. Estimates of Pearson correlations between the physical properties and indicators of soil organic matter in the 0.0-0.20 m layer

\begin{tabular}{|c|c|c|c|c|c|c|c|c|}
\hline & POM & MOM & TOC & CPI & LAB & $\mathbf{L I}$ & CMI & CACUM \\
\hline $\mathrm{BD}$ & $-0.71 * *$ & $-0.67 * *$ & $-0.72 * *$ & $-0.60 * *$ & $-0.72^{* *}$ & $-0.84 * *$ & $-0.80 * *$ & $-0.31^{\mathrm{ns}}$ \\
\hline MACRO & $0.62 * *$ & $0.58 * *$ & $0.62 * *$ & $0.48^{* *}$ & $0.65^{* *}$ & $0.74^{* *}$ & $0.68 * *$ & $0.21^{* *}$ \\
\hline MICRO & $-0.22^{\mathrm{ns}}$ & $-0.21^{\mathrm{ns}}$ & $-0.22^{\mathrm{ns}}$ & $-0.16^{\mathrm{ns}}$ & $-0.25^{\mathrm{ns}}$ & $0.32^{\mathrm{ns}}$ & $0.26^{\mathrm{ns}}$ & $0.04^{\mathrm{ns}}$ \\
\hline $\mathrm{TP}$ & $0.64^{* *}$ & $0.60^{* *}$ & $0.64^{* *}$ & $0.50^{* *}$ & $0.66^{* *}$ & $0.74 * *$ & $0.69^{* *}$ & $0.23^{\mathrm{ns}}$ \\
\hline MGD & $0.54^{*}$ & $0.69^{* *}$ & $0.65^{* *}$ & $0.60^{* *}$ & $0.56^{*}$ & $0.67^{* *}$ & $0.65^{* *}$ & $0.58 * *$ \\
\hline MWD & $0.56^{* *}$ & $0.73^{* *}$ & $0.68 * *$ & $0.64^{* *}$ & $0.57 * *$ & $0.69 * *$ & $0.68^{* *}$ & $0.64^{* *}$ \\
\hline$>1 \mathrm{~mm}$ & $0.58 * *$ & $0.75^{* *}$ & $0.70 * *$ & $0.66^{* *}$ & $0.59 * *$ & $0.71 * *$ & $0.69 * *$ & $0.67 * *$ \\
\hline$<1 \mathrm{~mm}$ & $-0.58 * *$ & $-0.75^{* *}$ & $-0.70 * *$ & $-0.66^{* *}$ & $-0.59 * *$ & $-0.71 * *$ & $-0.69 * *$ & $-0.67 * *$ \\
\hline
\end{tabular}

** and * significant by the t test at $1 \%$ and $5 \%$ respectively; ns, non-significant. BD: soil density; MACRO macroporosity; MICRO: microporosity, TP: total porosity; MGD: mean geometric diameter, MWD: mean weight diameter; > 1mm: aggregates larger than $1 \mathrm{~mm}$; <1 mm: aggregates smaller than $1 \mathrm{~mm}$; POM: particulate organic matter; MOM: mineral-associated organic-matter, TOC: total organic carbon; CPI: carbon pool index; LAB: lability, LI: lability index, CMI: carbon management index; CACUM: accumulated carbon. 


\section{CONCLUSIONS}

1. The integrated crop-livestock system promotes changes in soil physical and chemical properties, and the effects of the different crop rotation systems are mainly noticeable in the surface soil layer (0.0 $0.05 \mathrm{~m}$ );

2 . The crop rotations in integrated crop-livestock system allowed the maintenance of soil carbon levels equal to those of the native forest, proving the efficiency of these systems and of soil carbon as an indicator of the sustainability of a system with regard to soil conservation;

3. The soil stability was positively influenced by the integrated crop-livestock systems, and the soil quality indicator mineral organic matter was best related to aggregate stability.

\section{ACKNOWLEDGEMENTS}

The authors are indebted to the Brazilian Federal Agency for Support and Evaluation of Graduate Education - CAPES, for granting a scholarship that made this work possible.

\section{LITERATURE CITED}

ALVARENGA, R.C. \& NOCE, M.A. Integração lavoura e pecuária. Sete Lagoas, Embrapa Milho e Sorgo, 2005. 16p. (Documentos, 47).

ARGENTON, J.; ALBUQUERQUE, J.A.; BAYER, C. \& WILDNER, L.P. Comportamento de atributos relacionados com a forma da estrutura de Latossolo Vermelho sob sistemas de preparo e plantas de cobertura. R. Bras. Ci. Solo, 29:425-435, 2005.

BAYER, C.; MARTIN NETO, L.; MIELNICZUK, J. \& PAVINATO, A. Armazenamento de carbono em frações lábeis da matéria orgânica de um Latossolo Vermelho sob plantio direto. Pesq. Agropec. Bras., 39:677-683, 2004.

BERGAMIN, A.C.; VITORINO, A.C.T.; FRANCHINI, J.C.; SOUZA, C.M.A. \& SOUZA, F.R. Compactação em um Latossolo Vermelho Distroférrico e suas relações com o crescimento radicular do milho. R. Bras. Ci. Solo, 34:681691, 2010.

BERTOL, I.; ALMEIDA, J.A.; ALMEIDA, E.X. \& KURTZ, C. Propriedades físicas do solo relacionadas a diferentes níveis de oferta de forragem de Capim-Elefante-Anão cv. Mott. Pesq. Agropec. Bras., 35:1047-1054, 2000.

BERTOL, I.; ALBUQUERQUE, J.A.; LEITE, D.; AMARAL, A.J. \& ZOLDAN JUNIOR, W.A. Propriedades físicas do solo sob preparo convencional e semeadura direta em rotação e sucessão de culturas, comparadas às do campo nativo. R. Bras. Ci. Solo, 28:155-163, 2004.
BERTOL, I.; GOMES, K.E.; DENERDIN, R.B.N.; ZAGO, L.A. \& MARASCHIN, G.E. Propriedades físicas do solo relacionadas a diferentes níveis de oferta de forragem numa pastagem natural. Pesq. Agropec. Bras., 32:779786, 1998.

BRAIDA, J.A.; REICHERT, J.M.; VEIGA, M. \& REINERT, D.J. Resíduos vegetais na superfície e carbono orgânico do solo e suas relações com a densidade máxima obtida no ensaio proctor. R. Bras. Ci. Solo, 30:605-614, 2006.

CALONEGO, J.C. \& ROSOLEM, C.A. Estabilidade de agregados do solo após manejo com rotação de culturas e escarificação. R. Bras. Ci. Solo, 32:1399-1407, 2008.

CARNEIRO, M.A.C.; CORDEIRO, M.A.S.; ASSIS, P.C.R.; MORAES, E.S.; PEREIRA, H.S.; PAULINO, H.B. \& SOUZA, E.D. Produção de fitomassa de diferentes espécies de cobertura e suas alterações na atividade microbiana de solo de cerrado. Bragantia, 67:455-462, 2008.

CARTER, M.R. Organic matter and sustainability. In: REES, R.M.; BALL, B.C.; CAMPBELL, C.D. \& WATSON, C.A., eds. Sustainable management of soil organic matter. New York, CABI, 2001. p.9-22.

CASSOL, L.C. Relações solo-planta-animal num sistema de integração lavoura-pecuária em semeadura direta com calcário na superfície. Porto Alegre, Universidade Federal do Rio Grande do Sul, 2003. 143p. (Tese de Doutorado)

CHRISTENSEN, B.T. Physical fractionation of soil and structural and functional complexity in organic matter turnover. Eur. J. Soil Sci., 52:345-353, 2001.

COLLARES, G.L.; REINERT, D.J.; REICHERT, J.M. \& KAISER, D.R. Qualidade física do solo na produtividade da cultura do feijoeiro num Argissolo. Pesq. Agropec. Bras., 41:1663-1674, 2006.

CORAZZA, E.J.; SILVA, J.E.; RESCK, D.V.S. \& GOMES, A.C. Comportamento de diferentes sistemas de manejo como fonte ou depósito de carbono em relação à vegetação de cerrado. R. Bras. Ci. Solo, 23:425-432, 1999.

COSTA, A.; ALBUQUERQUE, J.A.; MAFRA, A.L. \& SILVA, F.R. Propriedades físicas do solo em sistemas de manejo na integração agricultura-pecuária. R. Bras. Ci. Solo, 33:235-244, 2009

EMPRESA BRASILEIRA DE PESQUISA AGROPECUÁRIA EMBRAPA. Centro Nacional de Pesquisa de Solos. Manual de métodos de análise de solo. 2.ed. Rio de Janeiro, 1997. 212p.

EMPRESA BRASILEIRA DE PESQUISA AGROPECUÁRIA EMBRAPA. Centro Nacional de Pesquisa de Solos. Sistema brasileiro de classificação de solos. 2.ed. Rio de Janeiro, 2006. 306p.

FENG, G.; WU, L. \& LETEY, J. Evaluating aeration criteria by simultaneous measurement of oxygen diffusion rate and soil-water regime. Soil Sci., 167:495-503, 2002.

FERREIRA, F.P.; AZEVEDO, A.C.; DALMOLIN, R.S.D. \& GIRELLI, D. Carbono orgânico, óxidos de ferro e distribuição de agregados em dois solos derivados de basalto no Rio Grande do Sul - Brasil. Ci. Rural, 37:381$388,2007$. 
FREDDI, O.S.; CENTURION, J.F.; BEUTLER, A.N.; ARATANI, R.G. \& LEONEL, C.L. Compactação do solo no crescimento radicular e produtividade da cultura do milho. R. Bras. Ci. Solo, 31:627-636, 2007.

KEMPER, W.D. \& ROSENAU, R.C. Aggregate stability and size distribution. In: KLUTE, A., ed. Methods of soil analysis. 2.ed. Madison, American Society of Agronomy, 1986. p.425-441.

LANZANOVA, M.E.; NICOLOSO, R.S.; LOVATO, T.; ELTZ, F.L.F.; AMADO, T.J.C. \& REINERT, D.J. Atributos físicos do solo em sistema de integração lavoura-pecuária sob plantio direto. R. Bras. Ci. Solo, 31:1131-1140, 2007.

LOSS, A.; PEREIRA, M.G.; SCHULTZ, N.; ANJOS, L.H.C. \& SILVA, E.M.R. Carbono e frações granulométricas da matéria orgânica do solo sob sistemas de produção orgânica. Ci. Rural, 39:1077-1082, 2009.

NICOLOSO, R.S; LOVATO, T.; AMADO, T.J.C.; BAYER, C. \& LANZANOVA, M.E. Balanço do carbono orgânico no solo sob integração lavoura-pecuária no sul do Brasil. R. Bras. Ci. Solo, 32:2425-2433, 2008.

PAGLIAI, M.; MARSILI, A.; SERVADIO, P.; VIGNOZZI, N. \& PELLEGRINI, S. Changes in some physical properties of a clay soil in Central Italy following the passage of rubber tracked and wheeled tractors of medium power. Soil Tillage Res., 73:119-129, 2003.

PEDROTTI, A.; FERREIRA, M.M.; CURI, N.; SILVA, M.L.N.; LIMA, J.M. \& CARVALHO, R. Relação entre atributos físicos, mineralogia da fração argila e formas de alumínio no solo. R. Bras. Ci. Solo, 27:1-9, 2003.

RANGEL, O.J.P.; SILVA, C.A.; GUIMARÃES, P.T.G. \& GUILHERME, L.R.G. Frações oxidáveis do carbono orgânico de Latossolo cultivado com cafeeiro em diferentes espaçamentos de plantio. Ci. Agrotec., 32:429-437, 2008.

RIBEIRO JÚNIOR, J.I. Análises estatísticas no SAEG. Viçosa, MG, Universidade Federal de Viçosa, 2001. 301p.

ROSCOE, R. \& BURMAM, P. Tillage effects on soil organic matter in density fractions of a Cerrado Oxisol. Soil Tillage Res., 70:107-119, 2003.

ROSCOE, R.; BURMAM, P. \& VELTHORST, E.J. Disruption of soil aggregates by varied amounts of ultrasonic energy in fractionation of organic matter of a clay Latosol: Carbon, nitrogen, and ${ }^{13} \mathrm{C}$ distribution in particle-size fractions. Eur. J. Soil Sci., 51:445-454, 2000.
ROSCOE, R; MERCANTE, F.M. \& SALTON, J.C. Dinâmica da matéria orgânica de solo em sistemas conservacionistas: Modelagem matemática e métodos auxiliares. Dourados, Embrapa Agropecuária Oeste, 2006. 304p.

SALTON, J.C.; MIELNICZUK, J.; BAYER, C.; BOENI, M.; CONCEIÇÃO, P.C.; CARVALHO, A.C.; MACEDO, M.C.M. \& BROCH, D.L. Agregação e estabilidade de agregados do solo em sistemas agropecuários em Mato Grosso do Sul. R. Bras. Ci. Solo, 32:11-21, 2008.

SALTON, J.C.; MIELNICZUK, J.; BAYER, C.; FABRICIO, A.C.; MACEDO, M.C.M.; BROCH, D.L.; BOENI, M. \& CONCEIÇÃO, P.C. Matéria orgânica do solo na integração lavoura-pecuária em Mato Grosso do Sul. Dourados, Embrapa Agropecuária Oeste, 2005. 58p.

SERAFIM, M.E.; VITORINO, A.C.T.; PEIXOTO, P.P.P.; SOUZA, C.M.A. \& CARVALHO, D.F. Intervalo hídrico ótimo em um Latossolo Vermelho distroférrico sob diferentes sistemas de produção. Eng. Agríc., 28:654-665, 2008.

SHUKLA, M.K.; LAL, R. \& EBINGER, M. Determining soil quality indicators by factor analysis. Soil Tillage Res., 87:194-204, 2006.

SILVA, M.L.N. \& FERREIRA, M.M. Atributos físicos indicadores da qualidade do solo sob sistemas de manejo na bacia do alto do Rio Grande-MG. Ci. Agrotec., 29:719$730,2005$.

SILVA, J.E.; LEMAINSKI, J. \& RESCK, D.V.S. Perdas de material orgânico e suas relações com a capacidade de troca catiônica em solos da região de cerrados do oeste baiano. R. Bras. Ci. Solo, 18:541-547, 1994.

SIQUEIRA JÚNIOR, L.A. Alterações de características do solo na implantação de um sistema de integração agricultura-pecuária leiteira. Curitiba, Universidade Federal do Paraná, 2005. 93p. (Tese de Mestrado).

SOUZA, A.R.; SILVA, A.B. \& RESENDE, M. Influência da pressão exercida por pisoteio de animais na compactação do solo do Vale Pajeú, em Pernambuco. In: REUNIÃO BRASILEIRA DE MANEJO E CONSERVAÇÃO DO SOLO E DA ÁGUA, 12., Fortaleza, 1998. Anais... Viçosa, Sociedade Brasileira de Ciência do Solo, 1998. p.256-257.

SPERA, S.T.; SANTOS, H.P.; FONTANELI, R.S. \& TOMM. G.O. Integração lavoura-pecuária e os atributos físicos do solo manejado sob sistema plantio direto. R. Bras. Ci. Solo, 33:129-136, 2009. 
